\title{
Toward more uniform conflict disclosures: updated ICMJE conflict of interest reporting form
}

Previously published at www.cmaj.ca

$\mathrm{T}$ The great variability in the processes that different journals use to ask about and report authors' potential conflicts of interest creates confusion for authors, readers and the public. To help lessen this confusion, the International Committee of Medical Journal Editors (ICMJE) developed an electronic uniform disclosure form and placed it in the public domain in October 2009. The ICMJE member journals piloted the form, encouraged other journals to use it and invited feedback. We recognized that the reporting of competing interests is complex, nuanced and sometimes contentious, and thus we expected to modify the form based on feedback. We are grateful to the many authors, editors and other interested parties who took the time to comment on the form and its implementation. The issues raised ranged from technical problems about the correct deployment of the form (it requires the user to download the free Adobe 8.0 Reader or higher) to concerns about the ethics of enquiring about nonfinancial associations. The ICJME considered these valuable comments and revised the form at its most recent meeting.

We made several modifications. The major change in the form is the removal of the queries about potential competing interests of authors' spouses and minor children and about nonfinancial competing interests. People who commented about this issue made it clear that there is immense difficulty in defining competing interests beyond those that involve the direct exchange of money from an interested party to an individual author or the author's institution. Because the Committee continues to believe that there are situations in which indirect or nonfinancial factors could influence (or appear to influence) the conduct or interpretation of work, we replaced the specific questions with a single open-ended query (new Section 4) that asks, "Are there any other relationships or activities that readers could perceive to influence, or that give the appearance of potentially influencing, what you wrote in the submitted work?" This change places the onus on the person completing the form to identify and report appropriate nonfinancial competing interests. It is less intrusive than the previous queries and provides a locus where authors can report nonfinancial relationships that may be perceived as potential conflicts of interest.

With regard to the clarity of the form, each field now has a numeric designation. We have modified the language in the instructions and in the individual queries. To make the form more useful to non-native English speakers, we are creating a glossary of terms used in the form and will be posting guidelines for translating the form's instructions into multiple languages. The translations are particularly challenging because they must capture the essence of the queries rather than their literal meaning. The glossary and instructions will be available at www.icmje.org in the next few months; translations will be posted on the ICMJE website as they become available.

The new form, in English, is currently available on the ICMJE website and the websites of our member journals. Authors who have completed the older version of the form in conjunction with a journal submission need not complete the new form, but the new form will be the standard for new submissions. We welcome input from the user community. Comments can be sent via the "contact us" link at www.icmje.org. The committee will consider comments received before May 1, 2011, when we prepare the next iteration of the uniform conflict of interest disclosure form.

The complexity, subjectivity and emotionality of conflict disclosure ensures that some will consider this reporting form to be exces- sively burdensome while others will think it falls short in one area or another. We cannot, however, let the perfect be the enemy of the good. We hope that the revised ICMJE form will be another step toward simplifying and standardizing reporting of conflicts of interest. A more uniform reporting process will alleviate the confusion that prevails when multiple journals use different reporting formats and ease the reporting burden on members of the biomedical research community so they can pursue the research that will improve the care we can deliver to our patients. With these thoughts in mind, we encourage all journals to adopt the new version of the uniform disclosure form.

\section{Jeffrey M. Drazen MD}

Editor-in-Chief, New England Journal of Medicine

Peter W. de Leeuw MD PhD

Editor-in-Chief, Nederlands Tijdschrift voor Geneeskunde

(Dutch Journal of Medicine)

Christine Laine MD MPH

Editor, Annals of Internal Medicine

Cynthia Mulrow MD

Secretary, ICMJE

Catherine D. DeAngelis MD MPH

Editor-in-Chief, JAMA

Frank A. Frizelle MB ChB

Editor-in-Chief, The New Zealand Medical Journal

Fiona Godlee MB BChir BSc

Editor-in-Chief, $B M J$

Charlotte Haug MD PhD MSc

Editor-in-Chief, Norwegian Medical Journal

Paul C. Hébert MD MHSc

Editor-in-Chief, Canadian Medical Association Journal

Astrid James MBBS BSc

Deputy Editor, The Lancet

Sheldon Kotzin MLS

Associate Director for Library Operations, National Library of Medicine

Ana Marusic MD PhD

Editor-in-Chief, Croatian Medical Journal

Humberto Reyes MD

Editor, Revista Médica de Chile

Jacob Rosenberg MD DSc

Editor, Journal of the Danish Medical Association

Peush Sahni MS PhD

Representative and Past President, World Association of

Medical Editors

Martin B. Van Der Weyden MD

Editor, The Medical Journal of Australia

Getu Zhaori MD

Editor-in-Chief, China Medical Tribune

Competing interests: None declared.

Editor's note: This editorial is being published simultaneously in all ICMJE member journals.

Disclaimer: Dr Sahni's affiliation as representative and past president of the World Association of Medical Editors (WAME) does not imply endorsement by WAME member journals that are not part of the ICMJE.

CMAJ 2010. DOI:10.1503/cmaj.100793 